J. Natn. Sci. Coun. Sri Lanka 199220 (2) : 251-263

\title{
GEOMORPHOLOGY OF THE SOUTHERN COASTAL PLAIN
}

\author{
U. WEERAKKODY
}

Department of Geography, University of Ruhuna, Matara.

(Date of receipt : 17 June 1991)

(Date of acceptance : 25 September 1992)

\begin{abstract}
The southern coastal plain of Sri lanka is characterized by raised beaches, former barrier chains, fluviomarine plains, buried coral reefs, denudational hills etc. These landforms were surveyed by means of aerial photographs aided by field work. After completing geomorphological maps of the area, the landforms were classified on the basis of genesis, relative chronology and material. The units of landforms recognized were the marine, fluvial, fluviomarine, denudational and structurally controlled origin. The dominance of marine processes in the geomorphological evolution of the area persisted during the last six millennia and was strongly influenced by post-glacial sea level rise upto the mid-Holocene time and the lowering of the sea level thereafter.
\end{abstract}

Key words: Landforms, southern coastal plain, origin, sea level changes.

\section{INTRODUCTION}

Aerial photographs and satellite imagery have become major tools in the surveying and mapping of coastal features ${ }^{1,2}$ and its use in Sri Lanka has gradually been developed in the last decade. This has been used for the inventorization of engineering structures, natural vegetation etc. Attempts at mapping coastal processes can be found in studies by Swan ${ }^{3}$ where he has mapped the waves and swell of the South coast. The uses and limitations of aerospace techniques in studying landfrom evolution in depositional coasts have been analysed previously. ${ }^{4,5}$ An attempt was also made in the SW coast of Sri Lanka to map coastal features using large-scale balloon photographs. ${ }^{6}$ The mapping of coastal geomorphology of the southern coast of Sri Lanka, which is under severe abrasion and characterized by many landform units, by aerial photographs was carried out to test the capabilities of aerial survey.

\section{The area of study and its geologic setting}

The area considered in this study is situated between the bay of Galle and Walgama near Matara (Figure 1). The bay of Weligama situated in the middle part of the area is excluded in the study because of its deep penetration into the interior of the country. The study area is located in the wet zone of the island, and receives an annual rainfall exceeding $1900 \mathrm{~mm}$ (75 inches). The coastal belt of the SW Sri Lanka faces the Lakadive region of the Equatorial Indian Ocean, as demarcated by Colborn, and changes its thermal conditions in the period between May and 

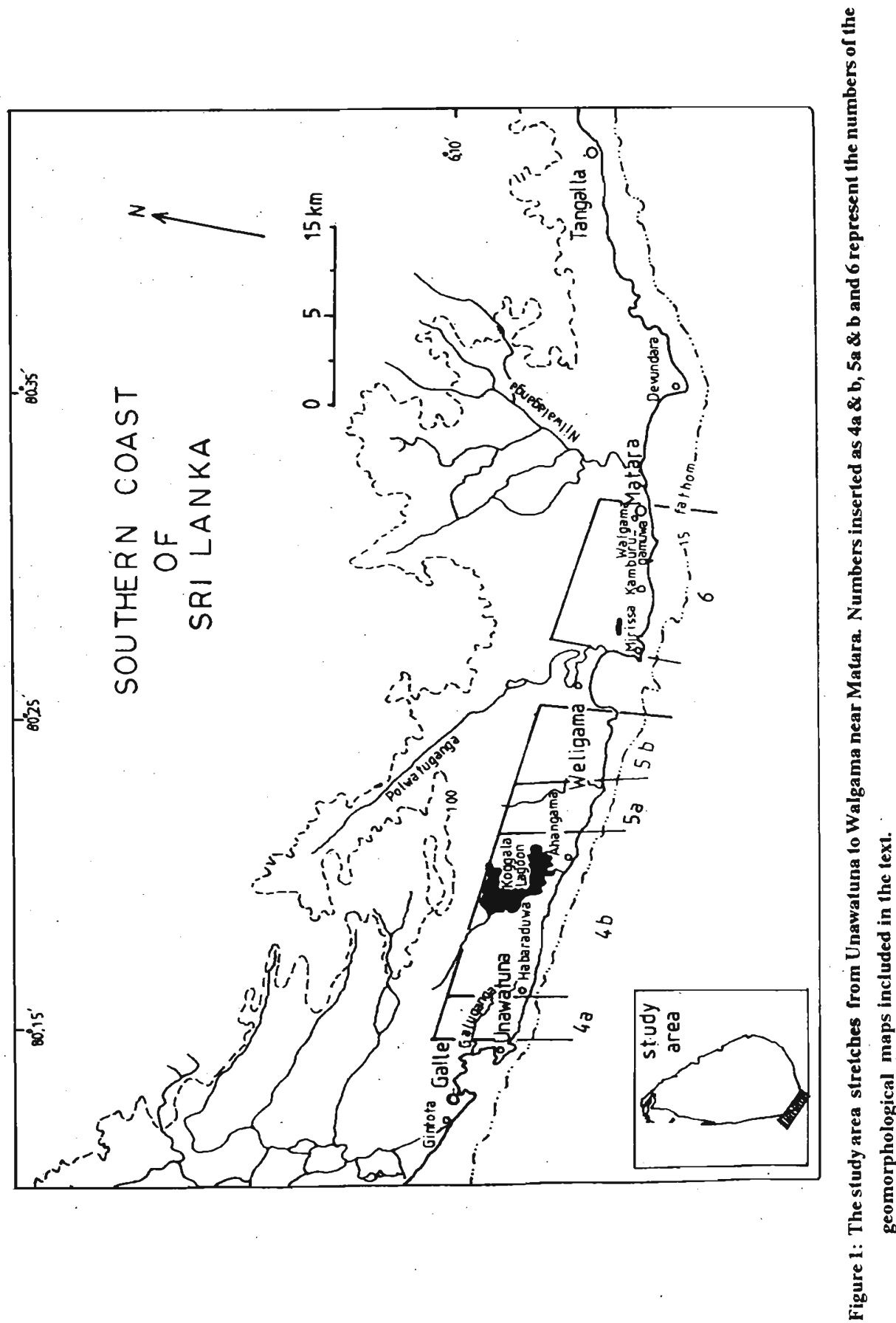
September. Landforms of the coastal plain mostly exhibit a marine influence, since the high sea levels during the Quaternary submerged the coastal zone of the study area. $1,8,9$ In addition, ancient marine landforms as well as landforms altered by marine action in the immediate hinterland are the result of the rise and fall of the sea level since the mid-Holocene time. ${ }^{5}$ The genesis of landforms is complicated considerably due to the everchanging processes acting on the coastal zone. The Holocene events of the Koggala area, for example, are illustrated in Figures 2 a \& b.

The Southwestern Group, a part of the Precambrian rock formations described by Cooray ${ }^{10}$ dominates the geology of the entire study area. The major rock types of the Southwestern group, according to Cooray, ${ }^{10}$ are metasediments, charnockites and granite/pegmatites. The charnockites and undifferentiated metasediments occur in the coastal plain concurrently with bands of diopside-scapolite (mainly woollastonite bearing) calc-granulites or gneiss. ${ }^{11}$

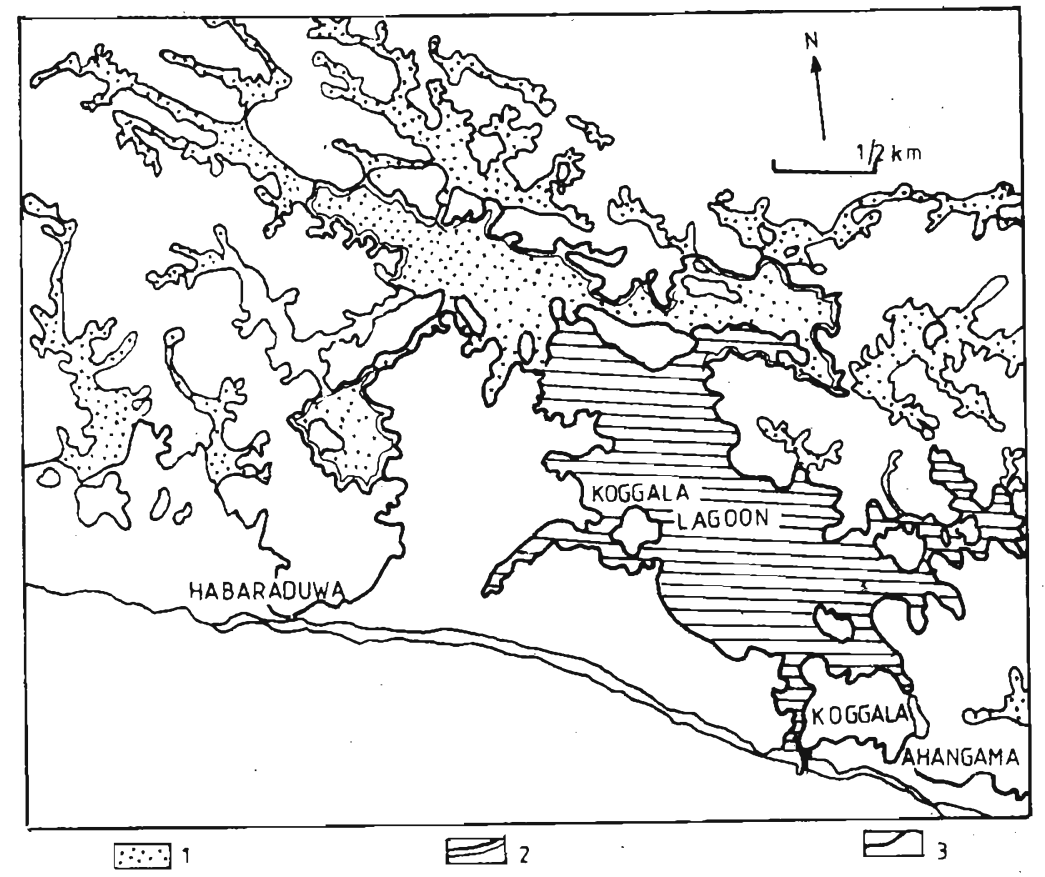

Figure 2a: The mid-Holocene events along the Koggala lagoonal plain. Velocity of the down flow has been decreased in association with the risen sea level. Accumulation of alluvium in the valleys has begun to form alluvial plains (1). The risen water level of the lagoon has encroached into the low valleys (2). The submerged area has formed an irregular embayment (3). 


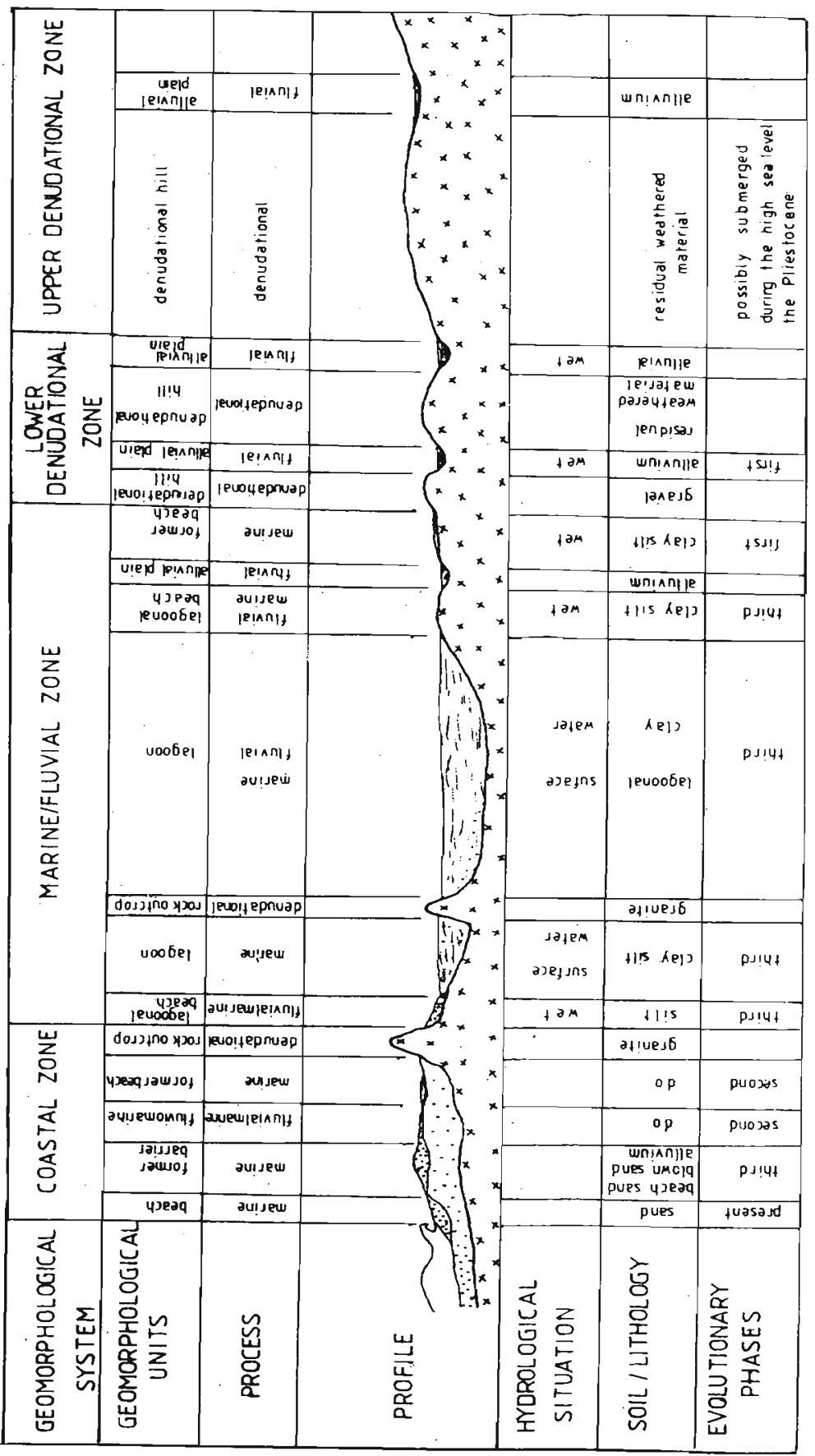

过 
The area can be divided into two distinct lithologic parts; the northern portion stretches from Galle to Habaraduwa and consists of charnockites (hypersthene, diopside gneiss or granulite bearing hornblend biotite) and charnockite-gneiss, while the southern part extends from Habaraduwa to the Nilwala River mouth and comprises undifferentiated metasediments. Quatzites are mainly confined to the zone of charnockites along the coastal belt. They are of minor extent and cannot be traced for distances. Calc-granulites and gneisses occur throughout the area and have been traced for over $16 \mathrm{~km}$. At places bands of calc-granulite are exposed eg. Rumassala, Habaraduwa and Ahangama. They form headlands and rock outcrops projecting into the sea with higher insulation on wave action as compared to similar features in other types of rocks.

Even though the hinterland is occupied by such types of old rocks, the coastal area is covered predominantly by Quaternary deposits (Figure 3). The river alluvium and the lagoonal deposits (clay, silt and sand), marine deposits (beach sand, beachrock and coral debris) and aeolian deposits (dune and windblown sand) are Holocene, while the partly ferruginous gravels are Pleistocene. The Holocene coral formations can be divided into two types excluding the living reefs offshore viz. a) raised reefs in the immediate hinterland, b) buried coral debris washed off from living reefs by storm waves. The raised reefs and buried debris accumulation were formed during the mid-Holocene period.

\section{METHODS AND MATERIALS}

A preliminary stereoscopic interpretation of black-and-white aerial photographs at a scale of 1:10,000 dating from 1987 was carried out in the Department of Physical Geography, University of Augsberg (FRG). The classification and mapping of landfroms followed in the present study is based on the ITC system of geomorphological survey. ${ }^{12,13}$ Accordingly, a tentative classification was developed using criteria such as genesis, processes and relative chronology. After several revisions, the legend of the geomorphological map was finalized to represent each landform in its specific geomorphological context. The results of a detailed geomorphological survey of landforms were compiled into sectional maps showing the landforms and their boundaries, the sequential stages of landforms, geomorphological details and a classification of landforms according to an arranged key.

Since the area contains landforms which had been later altered by marine processes, combined criteria on the genesis were given special attention. i.e. marine/fluvial. The categories thus distinguished are landforms of a) marine origin, b) fluvial origin, c) denudational origin, d) structurally controlled origin, and e) marine/fluvial origin. 
Each category of landforms classified on the basis of the processes was further subdivided into sea beach, barrier etc. The (relative) chronological criterion was used to recognize the temporal sequences of the subdivision of landforms such as sea beach (SB), former sea beach 1 (SBf 1), former sea beach 2 (SBf 2) etc., where 1 denotes the oldest stage while 2 stands for the second oldest stage of the formation. The word 'former' or 'abandoned' without numbers were used to indicate relative age where no more than one sequential stage occurs.

Forms which could not be demarcated distinctively due to their small size were classified in geomorphological details, such as wave-cut terraces, groynes etc. and marked by a special symbol. Active processes of the past and the present were also symbolized under the section of geomorphological detail.

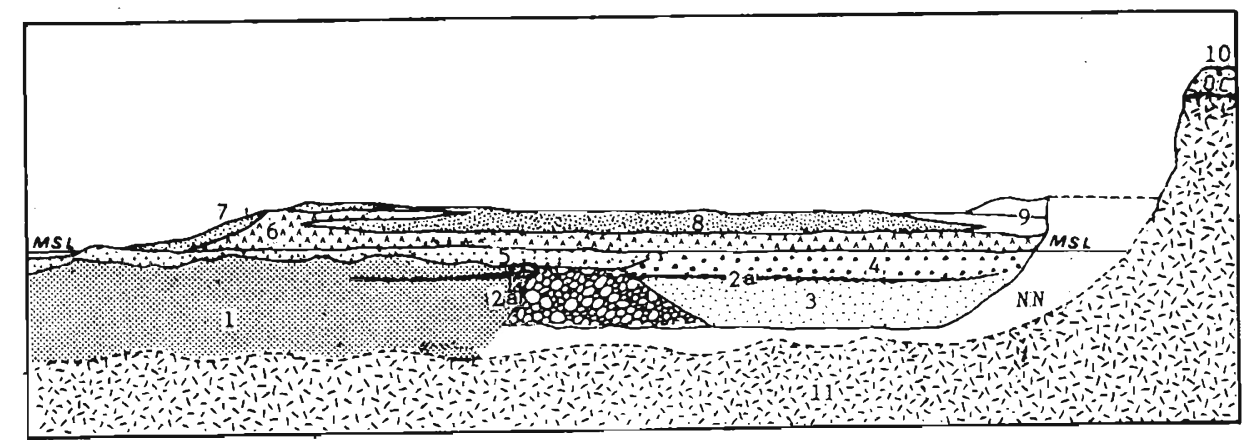

Figure 3: Geological cross-section of the southern coastal plain of Sri Lanka. 1) Fine sand, 2) Coral reefs 2a) Fragments and masses of coral, 3) Gray sandy clay, 4) Consolidated sand, 5) Sandstone, 6) Peat and sea sand, 7) Recent beach sand and blown sand, 8) Peat, 9) Ancient beach and blown sand, 10) Implementiferous plateau gravels, 11) Ancient crystalline rocks. $\mathrm{NN}=$ Not named (redrawn from Wayland) .15

All mapping units demarcated on the tentative geomorphological map were field-surveyed and representative samples were collected from landforms identified as being of marine origin. Present marine landforms such as buried coral reefs and their debris, marine shell beds etc. were given special attention because a proper identification and demarcation could not be made with aerial photographs. During field work, the materials of the landforms were also studied at numerous localities from profiles obtained by augering/lamination of marine deposits, the textural grain 
[y.tid marshond

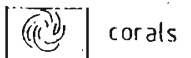

$\pi$ Tave

advance through

[. 1 direction of longshore drift

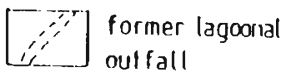

$4^{4}$ escarpment

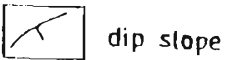

\section{beachrock \\ $1960 \pm 60 \quad C_{14}$ dating

$$
\left[\begin{array}{l}
-1 \\
-1
\end{array}\right. \text { wave }
$$

GEOMORPHOLOGICAL UNITS

Units of marine origin

BS sea beach

SBf former sea beach

SBll former sea beach (first generation)

SBI2 rormer sea basch (second generation)

BAf former barrier

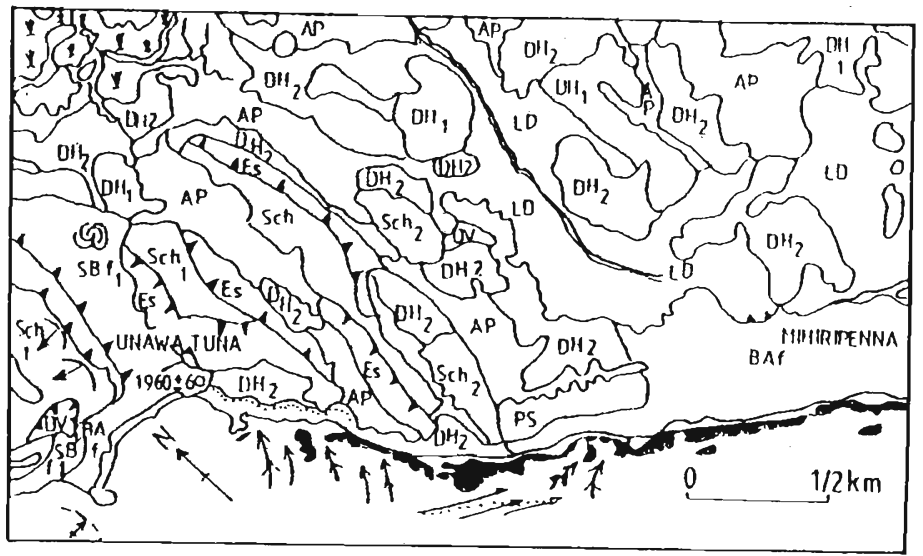

(a)

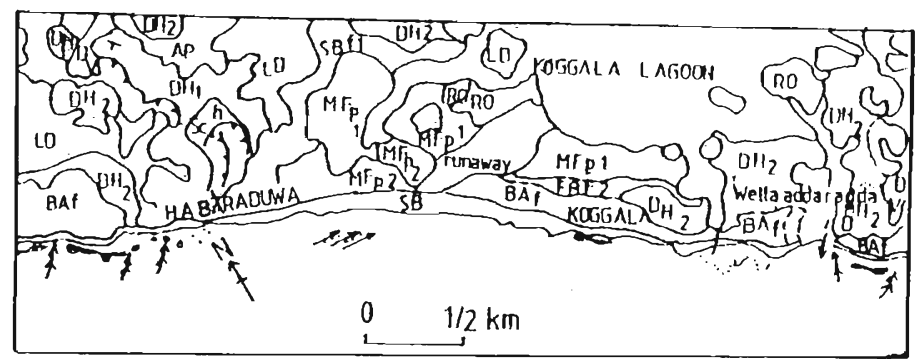

(b)

Units of denudational origin

Units of fluvial and fluviomarine origin

DH1 denudational hill (high)

AP alluvial plain.

$\mathrm{DH} 2$ demdational hill (low)

LU dried lagoon

DV denudational valley

PS planation surface

Schl structurat hill (high)

MFp1 fluviomarine plain (first generation)

Mlp2 fluviomarine plain (second generalion)

Sch2 structural hill (low)

Es escarpment zone

Figure $4 a \&$ b: The geomorpholgy of the coastal plain stretches from Unawatuna to Mihiripenna (a) and from Mihiripenna to Wella-addaragoda (b). 
size of the materials and their colours were carefully studied. After completion of the field work the tentative geomorphological map, clearly show that they have developed under marine influences during the mid-Holocene period.

\section{Geomorphology of the study area}

The landforms of marine origin: The sea beaches (SB) formed by very recent marine processes dominate the entire study area except in places characterized by cliffs, rock outcrops (RO), etc. The recent sea beach occupy the foot of the former barrier chains (BAF) which have been turned into terraces with heights varying from 1 to $11 / 2 \mathrm{~m}$. The terraces can be commonly observed along the coasts where severe erosion of the former barrier chains have occurred, i.e. the Ahangama and Akurala coastal tracts. The former sea beaches (SBf 1, SBf 2) can only be observed along parts of the study area as remnants because the continuous formations of the former beaches have been destroyed by anthropogenic factors. A well developed former sea beach can be seen around Walgama when the mid-Holocene high sea level encroached further inland (Figures $4 a \& b$ ). An analysis of the samples derived from Walgama unravels the environment in which the former beach was formed. In addition, the samples exhibit different types of materials, i.e. coral debris, beach sands and beach sands admixed with alluvium.

Former barrier chains (BAf) are observed along the Talpe Ahangama tract. They are broad and long running parallel to the present beaches. Most of the former barrier chains have grown by way of connecting two headlands of former embayments formed by an early period of submergence (Figure 6). The height of these barrier chains is $1-11 / 2 \mathrm{~m}$, neglecting the height of windblown sand. The height suggests that a lowering of the sea level occurred between the formation of barrier chains and the present shoreline.

The most important feature of the barrier chains is the formation of littoral sandstones or beachrock underneath them (Figure 6). Their exposition indicates the amount of degradation of the chains. Some of the exposed beachrocks are now partially or completely inundated. 


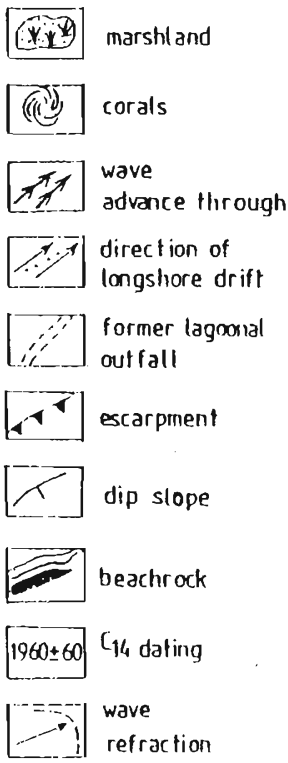

GEOMORPHOLOGICAL UNITS Units of marine origin

BS sea beach

SBf former sea beach SBIl former sea beach
(f irst generation) SBI2 former sea beach (second generation)

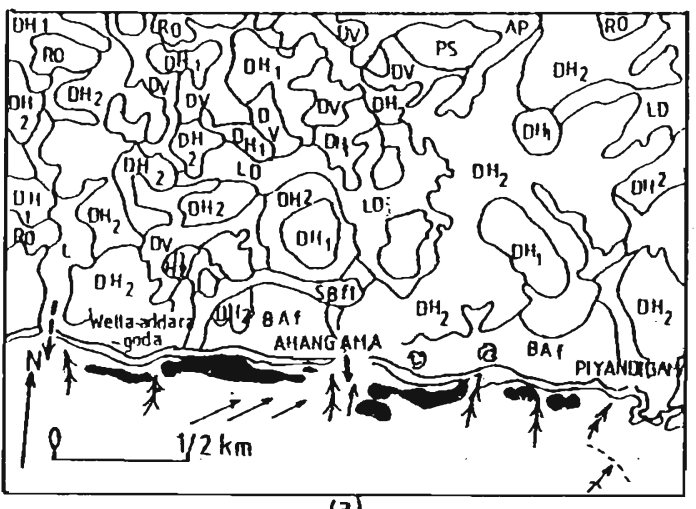

(a)

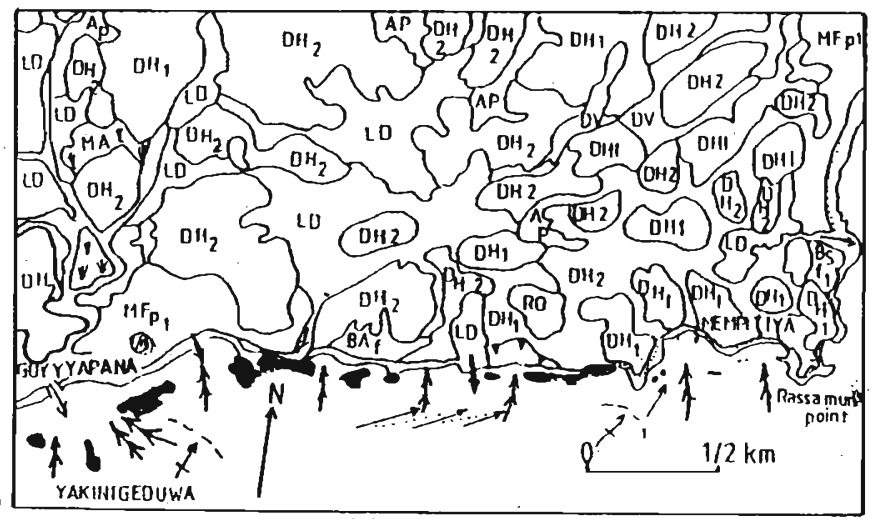

BAf former barrier

(b)

Units of fluvial and fluviomarine origin Units of denudational origin Units of structurally controlled origin
AP alluvial piain
DHl denudational hill (high) Schl structural hill (high)
LU dried lagoon
UH2 derudational hill (low)
Sch2 structural hill (low)
MTpi fluviomarine plain (first generation)
11 F12 rluviomarine plain (second generation)
UV denudational valley Es escarpment zone
PS planation surface

Figure 5a \& b: Geomorphology of the coastal plain streches from Wella-addragoda to Plyandigama (a) and from Goyyapana to Rassamuna Point (b). 


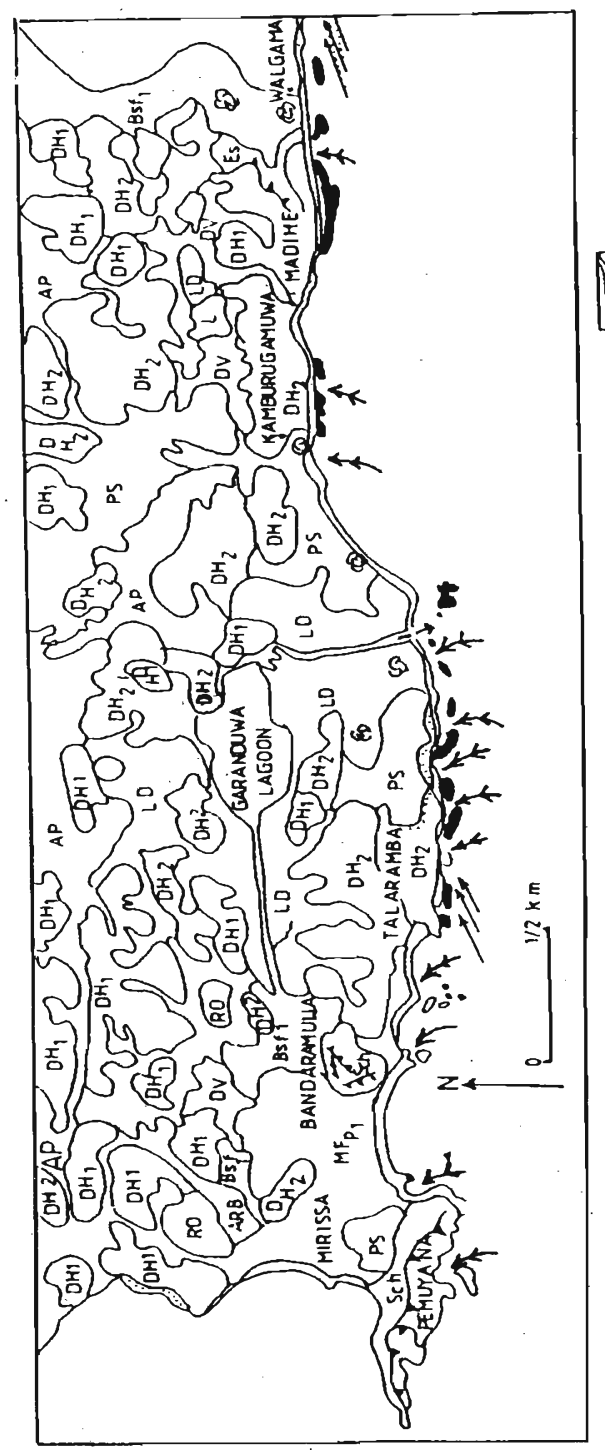

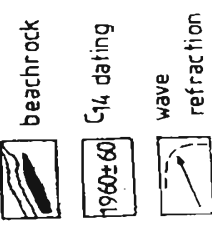

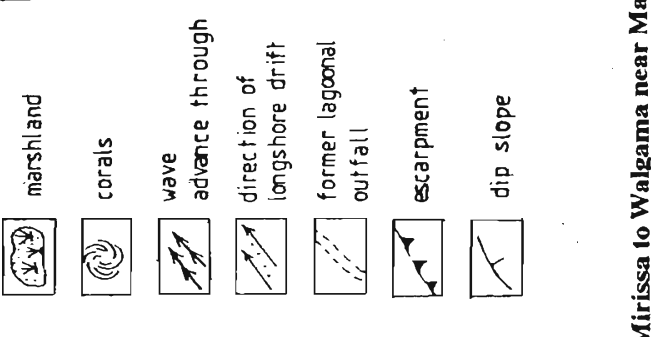

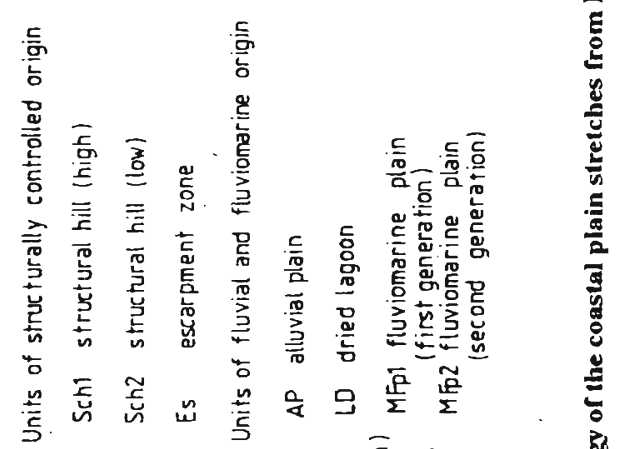

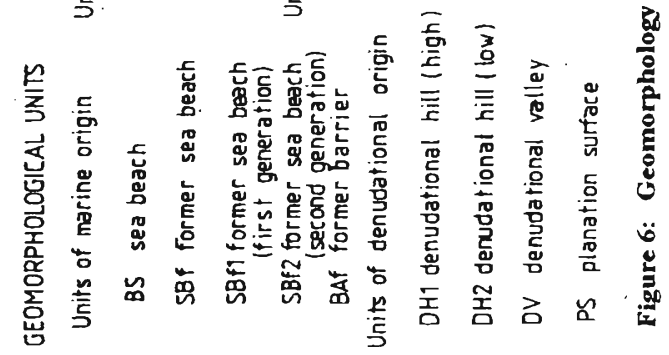


The landforms of fluvial and fluviomarine origin: Many parts of the lowlands are filled to form alluvial plains (AP). The fluviomarine plains (MFP) are the result of marine and fluvial processes as clearly shown by the composition of their sediments: beach sand admixed with fluvial sediments. Many fluviomarine plains occur where lagoonal waters submerged the lowlands (Figures $4 \mathrm{~b} \& 6$ ). Lagoons (L) and associated features vary both spatially-and temporally and thus are complex geomorphological features in the study area. The lagoons were formed by a rise in sea level. Landforms such as marshlands (MA), dried out lagoonal floors (LD), abandoned outfalls were consequently formed.

The landforms of denudational origin: The units of denudational origin consist of denudational valleys (DV), hills in two levels (DH 1 and DH2) and planation surfaces (PS). They are the dominant in situ landforms in the area (Figures 4, $5 \& 6$ ), and are in most instances covered by residual weathered products and/or . lateritic caps. Swan ${ }^{14}$ observed the flat-topped features of such landforms at elevations of 10-15, 40-60 and 90-120 feet above MSL. He suggested that they may have developed in association with eustatic changes, since they carried no fossils and were not buried under beach type accumulation. It is clear that the mid-Holocene sea level submerged only the foothills. 1,9

The denudational valleys and planation surfaces are the products of severe weathering in the tropical climate. Planation surfaces separated by denudational valleys or alluvial plains form a major geomorphological feature in the areas underlain by Precambrian rocks of the hinterland. The denudational valleys were formed by early incision predating the mid-Holocene rise in sea level, and were later buried by marine, fluvial and aeolian deposits. Planation surfaces of the study area in wet tropical conditions are somewhat different from those of the Southeast coast, formed under dry tropical climatic conditions. The southwestern type is flat and smoothy sloping in comparision to the southeastern type which possess rounded tops and moderately high angled slopes. The other denudational units along the study area are the outcrops which stand on the shore area. The rock outcrops devoid of residual weathered materials are always located near former lagoonal beds or attached to them.

The landforms of structurally controlled origin: The structurally controlled landforms are least affected by denudational processes and are characterized by structural features such as dip slopes and escarpments. Therefore, they can be recognized as structurally controlled hills in two levels (Sch 1 and Sch 2) and escarpment zone (Es). Their other distinctive properties are relatively high elevation, sharp boundaries and a steep slope angle. The elevation of the structurally controlled hills of Rumassala and Mirrissa for example, are 30 and $60 \mathrm{~m}$ above MSL respectively. (Figure 4 ). Swan ${ }^{14}$ concluded that the flat-topped areas which are situated in between 27 to $36 \mathrm{~m}$ above SL, eveloped as a result of eustatic changes of the sea level. 
Distinctive evidence for such changes at these elevations is difficult to obtain due to alternation by recent processes and/or anthropogenic influences. However, it is interesting to note here that the structurally controlled hills also occur in two levels as the denudational hills. Another distinctive feature of the structurally controlled hills is that the escarpment zones face denudational hills.

\section{CONCLUSIONS}

The spatial variations of the landforms of the study area are related to the genesis, relative chronology and materials produced by different processes. In addition, the lithology of the area creates at places specific landforms, e.g. structurally controlled hills. Even though the genesis of landforms is brought about by various processes, the marine influence operating in the area since mid-Holocene times dominates the geomorphologic scenery except in a few regions of high relief. The latter are mostly characterized by denudational hills, e.g. the Goyyapana and Mempitiya coastal tracts and are devoid of depositional landforms, e.g. the Akurala coast. The dominance of marine processes in the geomorphological evolution of the study area persisted during the last six millennia and has been governed strongly by the post-glacial sea-level rise up to the mid-Holocene time and its subsequent lowering.

With respect to the spatial variation of the geomorphology influenced by various factors such as the rise and fall of sea level, the geologic setting, the relief, relative chronology non-marine processes acting upon the landforms etc. it should be noted that not all the coastal tracts have evolved in similar sequential phases. Regional variations of the evolutional history of the study area thus occur.

\section{Acknowledgements}

This research was performed in 1987 - 1989. I thank the Natural Resources, Energy and Science Authority of Sri Lanka (NARESA) for financial support (Grant No RG/89/E/6) and Gesselschaft fur Technische Zusammenarbeit (GTZ) GmbH of FRG for financial support at the University of Augsberg.

\section{References}

1. Verstappen H. Th. (1987). Geomorphological studies on Sri Lanka with special emphasis on the northwest coast. International Training Centre for Aerial Survey Journal 1:1-17.

2. Wilson W.N. (1984). Terrain analysis using the aerial photo interpretation techniques; A case study of the area around Valachchanai in NE Sri Lanka. Unpublished M.A. Thesis, University of Colombo. 
3. Swan B. (1982). The coastal geomorphology of Sri Lanka; An introductory survey. National Museum, Colombo.

4. Weerakkody U. (1985). Landform evolution and sediment dynamics of depositional coasts; An aerospace survey approach. unpublished script, International Training Centre for Aerial Survey, the Netherlands.

5. Weerakkody U. (1988). Mapping of geomorphologic evolution using aerial photographs. International Training Centre for Aerial Survey Journal 2:185-98.

6. Preu C., Nashold G. \& Weerakkody U. (1987). Der finsatz einer ballon-fotoeinrichtung fur kustenmorphologische fragestellungen. Berliner Geographische Studien 25: 377-88.

7. Colborn G.L. (1975). The thermal structure of the Indian Ocean. pp 31-66 The University Press of Hawaii, Honolulu.

8. Swan B. (1964). Evidence for eustatic changes in southwest Ceylon. M.A. Thesis, University of London.

9. Weerakkody U. (1987). Mid-Holocene sea level changes in Sri Lanka. Joumal of the National Science Council of Sri Lanka 16(1):23-37.

10. Cooray P.G. (1967). An Introduction to Geology of Ceylon. pp 85-109. .National Museum, Colombo.

11. Geological Survey Department of Sri Lanka (1982). Geological map of Sri Lanka.

12. Van Zuidam R.A. \& Van Zuidam Cancelado F.I. (1978). Terrain Classification and Analyses. Vol VI, International Training Centre for Aerial Survey, Netherlands.

13. Verstappen, H. Th. (1977). Remote Sensing in Geomorphology. pp 101-25 Elservier Science Publication Company, Amsterdam.

14. Swan, B. (1967). Characteristics of coastal sands and their depositional environments in southwest Ceylon. Tropical Geographer 24: 30-42.

15. Wayland E.J. (1967). in An Introdiction to Geology of. Ceylon Ed. P.G. Cooray, pp 167, National Museum, Colombo. 